\title{
KERAGAAN EKONOMI USAHA KECIL DAN MENENGAH (UKM) \\ PENGOLAHAN OPAK SINGKONG DI DESA TUNTUNGAN II KABUPATEN DELI SERDANG SUMATERA UTARA
}

\author{
MAILINA HARAHAP \\ Dosen Fakultas Pertanian Universitas Muhammadiyah Sumatera Utara \\ email : Ummi_ahsan@yahoo.co.id \\ SITI MUJIATUN \\ Dosen Fakultas Ekonomi Universitas Muhammadiyah Sumatera Utara
}

\begin{abstract}
ABSTRAK
Komoditi pertanian sebagian besar adalah komoditi yang cepat rusak apabila tidak langsung dikonsumsi ataupun dilakukan proses pengolahan lanjut. Adapun dengan pengolahan lanjut, mampu memberikan nilai tambah (value added) terhadap komoditi pertanian. Hal tersebut ditunjukkan dengan Usaha Kecil dan Menengah Masyarakat (UKM) yang mampu mengakomodasi keberadaan sumberdaya manusia. Sebagaimana Harahap, Mailina (2013) mengemukakan bahwa UKM mempunyai potensi untuk dapat menimbulkan dampak pembangunan yang strategis dalam ekonomi terutama dalam aspek peningkatan nilai tambah, aspek pemerataan kesempatan kerja dan penyerapan tenaga kerja dalam mengatasi pengangguran, kemiskinan dan urbanisasi.

Sampel penelitian adalah pengusaha UKM Opak Singkong di desa Tuntungan II Kabupaten Deli Serdang dengan jumlah 30 orang. Hasil penelitian menunjukkan bahwa untuk memproduksi Opak Singkong, pengusaha menggunakan biaya tetap (fixed cost) Rp.644.497,5 dan biaya berubah (variable cost) Rp.3.379.450,01. Adapun biaya implisit sebesar Rp.13.010,07. Sehingga rata-rata biaya total (total cost) untuk setiap produksi Opak Singkong adalah Rp. 4.036.957,58. Penggunaan biaya yang besar terdapat pada pembelian bahan baku utama yaitu Singkong dengan penggunaan biaya sebesar Rp.3.173.166,67. Untuk setiap produksi Singkong yang digunakan rata-rata 2,4 ton.

Penerimaan pengusaha dari setiap produksi Opak adalah Rp.5.067.550,00 dengan jumlah produksi rata-rata $785,67 \mathrm{Kg}$ dengan harga $\mathrm{Rp} \cdot 6.450,00 / \mathrm{Kg}$. Dengan demikian ratarata keuntungan yang diperoleh pengusaha pada setiap produksi Opak adalah Rp.1.030.592,42. Hasil analisis kelayakan menunjukkan bahwa R/C sebesar 1,26. Dengan demikian kegiatan Usaha Kecil dan Menengah (UKM) Opak Singkong layak untuk dilanjutkan. Pola pemasaran Opak Singkong adalah pengusaha Opak selain sebagai produsen juga sebagai penjual kepada pabrik cemilan di Jakarta, Palembang dan Tanjung Morawa. Informasi pemasaran Opak tidak jelas diketahui sehingga margin keuntungan pemasaran Opak Singkong di desa Tuntungan II Kabupaten Deli Serdang tidak diketahui.
\end{abstract}

Kata kunci: UKM, Pengolahan Opak Singkong, Ekonomi Finansial, Lembaga Pemasaran

\section{A. PENDAHULUAN}

Pembangunan nasional secara keseluruhan tidak terlepas dari pembangunan pertanian. Dengan kata lain, konsep pembangunan menempatkan pembangunan pertanian sebagai mesin penggerak utama (prime mover) perekonomian nasional. Secara langsung pembangunan pertanian memberikan implikasi terhadap pertumbuhan ekonomi. Hal tersebut didorong oleh peran sektor pertanian yang strategis dalam menyediakan lapangan kerja dan memanfaatkan 
sumberdaya alam untuk menopang kebutuhan hidup manusia. Selanjutnya sektor pertanian juga memberikan kontribusi terhadap Produk Domestik Bruto (PDB). Pada tahun 2010 Sektor pertanian menempati peringkat ke-2 memberikan kontribusi terhadap PDB yaitu sebesar Rp. 239,4 triliun setelah sektor industri pengolahan sebesar Rp380,9 triliun. (BPS. 2011).

Komoditi pertanian sebagian besar adalah komoditi yang cepat rusak apabila tidak langsung dikonsumsi ataupun dilakukan proses pengolahan lanjut. Adapun dengan pengolahan lanjut, mampu memberikan nilai tambah (value added) terhadap komoditi pertanian. Disamping itu juga dengan adanya kegiatan pengolahan lanjut pada komoditi pertanian, maka kegiatan perekonomian akan berkembang. Hal tersebut ditunjukkan dengan Usaha Kecil dan Menengah Masyarakat (UKM) yang mampu mengakomodasi keberadaan sumberdaya manusia. Sebagaimana Harahap, Mailina (2013) mengemukakan bahwa UKM mempunyai potensi untuk dapat menimbulkan dampak pembangunan yang strategis dalam ekonomi terutama dalam aspek peningkatan nilai tambah, aspek pemerataan kesempatan kerja dan penyerapan tenaga kerja dalam mengatasi pengangguran, kemiskinan dan urbanisasi.

Desa Tuntungan II merupakan salah satu desa sentra tanaman singkong di Kabupaten Deli Serdang Provinsi Sumatera Utara. Dengan adanya ketersediaan bahan baku Singkong, berimplikasi pada kegiatan masyarakat dengan Usaha Kecil dan Menengah (UKM) pada pengolahan Singkong menjadi produk makanan yang memberikan nilai tambah. Usaha pengolahan singkong tersebut menghasilkan produk Opak dan Keripik Singkong.

Kegiatan produksi Opak Singkong di desa Tuntungan II tersebut, menjadi salah satu penopang ekonomi masyarakat. Dengan adanya usaha pengolahan Opak, memberikan lapangan pekerjaan bagi masyarakat, mulai dari kegiatan usaha tani Singkong sampai pada usaha pengolahan Singkong menjadi Opak. Pengolahan Singkong menjadi Opak dilakukan dengan padat karya sehingga dalam setiap proses produksi Opak tidak terlepas dari peran tenaga manusia secara langsung. Disampinng itu usaha tersebut masih merupakan usaha warisan turun temurun sehingga masih diusahakan secara sederhana dan tidak memiliki volume penjualan yang direncanakan. Dalam proses produksinya juga masih bergantung dengan alam. Proses penjemuran Opak mengandalkan sinar matahari. Tidak jarang ketika musim hujan, pengusaha Opak banyak yang memberhentikan produksi sementara.

Usaha pengolahan Opak di desa Tuntungan II merupakan usaha andalan ekonomi masyarakat sehingga perlu untuk dikembangkan. Memperhatikan aspek pemasaran Opak Singkong yang telah ke luar Provinsi seperti Padang, Pekanbaru, Aceh, Palembang, Jakarta bahkan ke luar negeri seperti Malaysia. Maka sangat perlu dilakukan perhatian terhadap Usaha Kecil dan Menengah (UKM) pengolahan Opak Singkong untuk bisa berkembang dan memiliki daya saing baik di pasar domestik dan non domestik. Berdasarkan hal tersebut maka diperlukan sebuah penelitian awal untuk mengkaji Keragaan Ekonomi Usaha Kecil dan Menengah (UKM) Opak Singkong di Desa Tuntungan II.

\section{B. KAJIAN TEORITIS}

\section{Industri Kecil dan Usaha Kecil Menengah}

Badan Pusat Statistik (BPS) menggolongkan perusahaan industri pengolahan di Indonesia ke dalam empat kategori : a) Industri kerajinan rumah tangga : usaha industri yang mempunyai tenaga kerja $1-4$ orang, b) Industri kecil :usaha industri yang mempunyai tenaga kerja 5 - 19 orang, c) Industri sedang: usaha industri yang mempunyai tenaga kerja 20 - 99 orang dan d) Industri besar: usaha industri yang mempunyai tenaga kerja 100 orang atau lebih. Hal tersebut lebih didasarkan pada banyaknya tenaga kerja yang terlibat di dalamnya (yang bekerja di perusahaan industri) tanpa memperhatikan penggunaan mesin produksi serta tidak memperhatikan model kapital yang digunakan. 
Berdasarkan Surat Keputusan Menteri Perindustrian dan Perdagangan No. 589/MPP/KEP/10/1999, pengertian industri kecil adalah suatu kegiatan usaha industri yang memiliki nilai investasi sampai dengan 200 juta rupiah tidak termasuk tanah dan bangunan tempat usaha (http://www.dprin.go.id/idkm).

Industri kecil mempunyai kedudukan yang lemah karena sebagian besar usahanya bersifat perorangan tidak berakta notaris, dan secara ekonomis mempunyai posisi tawar yang lemah dalam pasar karena sifat usahanya yang tidak terorganisir. Para pengusaha industri kecil kurang menyadari pentingnya organisasi ekonomi seperti koperasi atau asosiasi sebagai sarana untuk menggalang kekuatan usaha bersama, tetapi lebih suka bekerja sendiri-sendiri bahkan kadang-kadang menjurus pada kompetisi yang merugikan, bahkan saling mematikan atau cut throat competition.

\section{Eksistensi dan Peranan Industri Kecil dalam Perekonomian Wilayah}

Menurut Thunk dalam Thoha (2000) bahwa ada enam faktor yang menjelaskan eksistensi industri kecil, yaitu : pertama, dampak transportasi dimana biaya transportasi mempunyai pengaruh yang signifikan terhadap biaya pemasaran untuk jenis barang tertentu atau pada tingkat retail ; kedua adalah pengaruh ukuran; ketiga adalah pengaruh penyesuaian dimana perusahaan kecil lebih mudah melakukan penyesuaian pada output dengan biaya yang lebih rendah dibandingkan dengan perusahaan besar karena mereka lebih padat karya atau menggunakan peralatan yang lebih sederhana; keempat adalah efektifitas, sebagai contoh pakaian yang diproduksi secara massal dengan harga yang lebih murah, nilainya akan lebih rendah bagi sebagian konsumen dibandingkan dengan pakaian yang dijahit secara khusus oleh penjahit kecil; kelima adalah pengaruh pengendalian dimana biaya pengendalian untuk industri kecil lebih rendah dibanding industri besar terutama industri yang berhubungan dengan seni atau kerajinan dan membutuhkan perlakuan yang khusus; keenam adalah berkaitan dengan perubahan dalam teknologi dan globalisasi.

Industri kecil mempunyai peranan yang strategis dalam menunjang perekonomian nasional yaitu dalam usaha pemerataan dan penyebaran industri sebagai usaha untuk mengentaskan kemiskinan, berperan dalam menunjang pertumbuhan agroindustri yang mengolah hasil pertanian menjadi produk yang mempunyai nilai tambah yang lebih tinggi (Simatupang, 1994). Demikian pula yang dikemukakan oleh Tambunan (2000) bahwa di Indonesia UKM terdapat pada semua sektor ekonomi dan kontribusinya yang besar terhadap kesempatan kerja dan pendapatan, khususnya di daerah pedesaan dan keluarga yang berpendapatan rendah, tidak dapat dipungkiri bahwa UKM penting bagi pembangunan ekonomi nasional.

\section{Teori Biaya}

Biaya menurut prinsip ekonomi dapat diartikan dengan apa yang dikorbankan untuk mendapatkan sesuatu (Putong, Iskandar. 2005). Konsep biaya dapat digolongkan pada biaya eksplisit (explicit cost) dan biaya implisit (implicit cost). Biaya eksplisit adalah biaya yang terlihat secara fisik, misalnya berupa uang yang dikeluarkan maupun melalui laporang keuangan. Biaya Implisit adalah biaya yang tidak terlihat secara langsung, misalnya biaya kesempatan dan penyusutan barang modal.

\section{a. Biaya Total (Total Cost) / TC}

Biaya total merupakan jumlah keseluruhan biaya produksi yang dikeluarkan, yang terdiri dari biaya tetap dan biaya variabel.

Biaya total dapat dihitung dengan menggunakan rumus sebagai berikut:

$$
\mathrm{TC}=\mathrm{FC}+\mathrm{VC}
$$

$$
\begin{array}{ll}
\text { Di mana: } & \text { TC }=\text { Biaya total }(\text { Total Cost }) \\
& \text { FC }=\text { Biaya tetap }(\text { Fixed Cost })
\end{array}
$$


Biaya variabel merupakan biaya yang besarnya tergantung pada tingkat produksi. Biaya variabel dapat dihitung dari penurunan rumus menghitung biaya total, yaitu:

\section{c. Biaya Tetap (Fixed Cost) / FC}

$$
\mathrm{VC}=\mathrm{TC}-\mathrm{FC}
$$

Biaya tetap (fixed cost) adalah biaya yang besarnya tidak tergantung pada jumlah produksi. Biaya tetap dapat dihitung sama seperti biaya variabel, yaitu dari penurunan rumus menghitung biaya total. Penurunan rumus tersebut, adalah:

$$
\mathrm{FC}=\mathrm{TC}-\mathrm{VC}
$$

\section{Teori Penerimaan dan Keuntungan}

Penerimaan adalah konsep yang menghubungkan antara jumlah barang yang diproduksi dengan harga jual per unitnya. Penerimaan dapat dirumuskan:

$$
\mathrm{TR}=\mathrm{P} \times \mathrm{Q}
$$

Dimana: $\quad \mathrm{TR}=$ Total penerimaan (Total Revenue)

$$
\begin{aligned}
& \mathrm{P}=\text { Tingkat harga jual } \\
& \mathrm{Q}=\text { Jumlah unit barang }
\end{aligned}
$$

Keuntungan atau profit merupakan tujuan dari kegiatan produksi. Keuntungan dapat diperoleh dalam jangka pendek maupun jangka panjang. Dalam jangka panjang keuntungan dibutuhkan untuk menambah dan memperbesar kapasitas produksi. Sedangkan jangka pendek, keuntungan diperlukan untuk mempertahankan kelangsungan usaha dan berhubungan dengan tingkat produksi yang memiliki unsur biaya dan penerimaan. Selisih antara penerimaan dan biaya disebut dengan keuntungan (profit). Jika selisih penerimaan dan biaya hasilnya negatif, maka perusahaan mengalami kerugian dan sebaliknya jika selisihnya positif maka perusahaan mengalami keuntungan. (Putong, Iskandar. 2002). Keuntungan dapat dirumuskan:

$$
\begin{aligned}
& \pi=\mathrm{TR}-\mathrm{TC} \\
\text { Dimana : } & \pi
\end{aligned}
$$

\section{Lembaga Pemasaran}

Setiap kegiatan produksi yang menghasilkan barang dan jasa untuk sampai ke konsumen dilakukan dengan pemasaran. Menurut Sudiyono (2001) lembaga pemasaran sebagai badan usaha atau individu yang menyelenggarakan pemasaran, menyalurkan jasa dan komoditi dari produsen kepada konsumen akhir serta mempunyai hubungan dengan badan usaha atau individu lain. Lembaga pemasaran menyebabkan harga produk dari produsen sampai ke konsumen akhir akan berbeda.

Pada lembaga pemasaran terdapat pedagang perantara yaitu individu-individu atau pengusaha yang melaksanakan berbagai fungsi pemasaran dalam pembelian dan penjualan barang serta ikut memindahkan barang dari produsen ke konsumen. Pedagang perantara melaksanakan kegiatan perdagangan sebagai propietor (pemilik), partnership (mitra) atau perusahaan koperas/nonkoperasi. Dengan demikian lembaga pemasaran memberikan peran aktif dalam penyaluran barang ataupun jasa untuk sampai ke konsumen akhir. Sebagaimana Hanif dan Dyah (2012) mengemukakan bahwa kegiatan pemasaran melibatkan lembaga pemasaran. Semakin banyak lembaga pemasaran yang terlibat maka akan terbentuk pola pemasaran baik secara sederhana maupun pola pemasaran yang cukup panjang. 


\section{METODOLOGI PENELITIAN}

Jenis penelitian yang dilakukan adalah penelitian kasus dengan mengambil lokasi penelitian di desa Tuntungan II Kabupaten Deli Serdang. Jenis data penelitian menggunakan data primer. Data primer diperoleh dengan metode wawancara yang merujuk pada Nazir (1999) dengan menggunakan panduan wawancara (interview guide) dan dilakukan juga wawancara mendalam (indepth interview) terhadap responden. Adapun jumlah sampel penelitian adalah 30 orang pengusaha Opak Singkong. Teknik pengambilan sampel dilakukan secara purposive sampling. Untuk melakukan analisis terhadap tataniaga Opak Singkong, menggunakan sampel pedagang yang diperoleh secara snowball sampling.

\section{Teknik Analisis Data}

a. Analisis Biaya

Biaya pengolahan opak singkong dihitung dengan rumus :

$$
\mathrm{TC}=\mathrm{FC}+\mathrm{VC}
$$

Di mana : $\mathrm{TC}=$ Biaya total $($ Total Cost $)$

$\mathrm{FC}=$ Biaya tetap (Fixed Cost)

$\mathrm{VC}=$ Biaya Variabel (Variable Cost)

\section{b. Analisa Penerimaan, Pendapatan dan Keuntungan Usahatani}

Penerimaaan pengrajin dihitung dengan rumus :

Keterangan :

$$
\mathbf{T R}=\mathbf{Q} \times \mathbf{P}
$$

TR : Total Revenue (Total Penerimaan)

Q : Jumlah Produk yang dihasilkan

P : Harga Jual Produk

Pendapatan pengrajin dihitung dengan rumus:

$$
\begin{aligned}
& \text { Pd }=\text { TR }- \text { TEC } \\
& \text { Pd }=\text { QxP }- \text { TEC }
\end{aligned}
$$

Keterangan :

Pd : Pendapatan

TR : Total Revenue (total penerimaan)

TEC : Total Eksplisit Cost (total biaya yang benar-benar dikeluarkan oleh pengusaha opak Singkong)

Keuntungan dihitung dengan rumus :

Keterangan :

$$
\pi=\mathbf{T R}-\mathbf{T C}
$$

$\pi:$ Keuntungan

TR : Total Revenue (total penerimaan)

TC : Total Cost (total biaya yang dikeluarkan oleh petani)

\section{Analisa Imbangan Penerimaan dan Biaya ( Ratio R/C )}

Total Penerimaan ( TR )

$\mathrm{R} / \mathrm{C}$ ratio $=$ Total Biaya $(\mathrm{TC})$

1) Jika R/C > TC , maka layak untuk diusahakan

2) Jika R/C $\leq T C$, maka tidak layak untuk diusahakan

\section{Pola dan Lembaga Pemasaran}

Untuk mengetahui pola dan lembaga tataniaga yang terdapat di desa Tuntungan II Kabupaten Deli Serdang, pengambilan sampel dilakukan dengan snow ball sampling yaitu 
menelusuri pedagang perantara yang terlibat dengan bertanya langsung kepada pengusaha Opak Singkong kemudian dilakukan penelusuran.

\section{Marjin dan Keuntungan Pemasaran}

Marjin Pemasaran dihitung dengan rumus :

Keterangan :

$$
\mathbf{M}=\mathbf{P r}-\mathbf{P f}
$$

M : Marjin Tataniaga

Pr : Harga Ditingkat Konsumen

Pf : Harga Ditingkat Pengrajin

Keuntungan lembaga tataniaga dihitung dengan rumus :

$$
\boldsymbol{\pi}=\mathbf{M}-\mathbf{B}
$$

Keterangan :

$\pi:$ Keuntungan Tataniaga

M : Marjin Tataniaga

B : Biaya Tataniaga

\section{Bagian Harga yang Diterima Pengrajin}

Bagian harga yang diterima pengrajin dihitung dengan rumus :

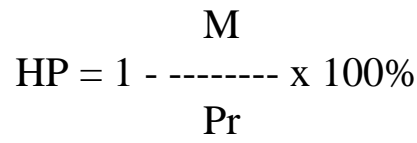

Keterangan :

$\mathrm{HP}$ : Bagian harga yang diterima pengrajin

$\mathrm{M}$ : Marjin tataniaga

Pr : Harga Ditingkat Konsumen

\section{HASIL DAN PEMBAHASAN}

\section{Karakteristik pengrajin Opak Singkong}

Umur responden pengusaha Opak Singkong pada umumnya adalah dalam usia produktif. Pada kelompok umur dapat diketahui bahwa kelompok umur yang paling banyak adalah pada umur 31 - 40 tahun dengan jumlah responden sebanyak 12 orang (40\%). Pada umumnya responden memiliki tingkat pendidikan formal selama 12 tahun atau setara dengan tingkat lulus SLTA. Bahkan terdapat satu orang responden yang memiliki pendidikan formal sampai jenjang Diploma. Adapun pendidikan non formal, tidak ada responden yang pernah mengikuti pendidikan nonformal. Dengan demikian responden belum pernah mengikuti penyuluhan, pelatihan ataupun pembinaan dari instansi tertentu. Pengalaman responden pengusaha Opak Singkong dalam mengelola usaha adalah 16-20 tahun sebanyak 9 orang (30\%) responden. Dengan demikian jika diperhatikan dari pengalaman usaha responden sudah cukup lama dalam mengusahakan produksi Opak Singkong. Hal tersebut pada umumnya disebabkan bahwa usaha yang dijalankan adalah merupakan usaha yang di wariskan dan turun temurun. Pada umumnya responden pengolah Opak Singkong merupakan kumpulan dari usaha keluarga. Pada umumnya jumlah tanggungan keluarga responden adalah berjumlah 4-6 orang. Adapun hal tersebut ditunjukkan dengan $70 \%$ responden memiliki jumlah anggota keluarga 4-6 orang.

\section{Produksi Opak Singkong}

Produksi Opak Singkong merupakan kegiatan idustri rumahtangga warisan. Dengan kata lain usaha Opak Singkong merupakan usaha yang sudah turun temurun di lakukan responden. Pada proses pengolahan Singkong menjadi Opak masih menerapkan bentuk kegiatan produksi sederhana. Responden belum melakukan inovasi dalam kegiatan produksi. 
Hasil produksi yang dipasarkan masih berupa Opak singkong. Adapun Opak Singkong yang dihasilkan belum memiliki cita rasa tertentu.

Bahan yang dibutuhkan pada proses produksi antara lain:

a. Singkong segar (bahan baku)

b. Bahan bakar

c. Kayu bakar

d. Air untuk merebus Singkong

Adapun Alat-alat yang digunakan antara lain:

a. Mesin diesel

b. Mesin Press untuk mengeringkan Singkong

c. Mesin penggiling Ubi Singkong agar halus

d. Mesin pencetak

e. Dandang untuk merebus Ubi singkong.

f. Ayakan untuk menyortir ukuran Opak Singkong

g. Plastik hitam untuk alas penjemur Opak yang telah selesai di cetak.

Proses produksi pengolahan Singkong menjadi Opak Singkong sebagai berikut:

a. Singkong segar dikupas lalu dibersihkan

b. Singkong yang telah dikupas dimasukkan ke dalam dandang besar berisi air mendidih dan direbus selama $2-3$ jam.

c. Setelah singkong lunak, ditiriskan.

d. Setelah ditiriskan Singkong dimasukkan ke dalam mesin press yang selanjutnya dimasukkan ke dalam mesin penggilingan.

e. Pada proses penggilingan Singkong yang telah halus langsung akan tercetak tipis-tipis dengan bentuk bulat dan kotak kecil-kecil.

f. Singkong yang keluar dari cetakan akan langsung ditampung oleh rak-rak penjemuran.

g. Proses penjemuran jika cuaca panas dapat dilakukan $2-3$ jam.

h. Setelah Opak Singkong kering dilakukan proses sortasi opak dengan menggunakan ayakan yang masih sederhana. Opak yang keluar dari ayakan artinya Opak yang rusak dan tidak layak untuk di kemas dan dipasarkan.

i. Proses terakhir adalah pengemasan Opak dengan memasukkan Opak ke dalam karung secara sederhana.

\section{Penggunaan Tenaga Kerja}

Tenaga kerja merupakan salah satu faktor-faktor produksi yang digunakan untuk menghasilkan Opak Singkong. Usaha pengolahan Opak Singkong menggunakan tenaga kerja laki-laki dan perempuan. Adapun tenaga kerja laki-laki digunakan pada proses perebusan sampai pengemasan Opak Singkong. Sedangkan tenaga kerja perempuan hanya mengerjakan proses pengupasan Singkong dan penjemuran Opak Singkong. Jumlah tenaga kerja yang digunakan tergantung pada banyaknya jumlah produksi Opak Singkong yang akan dihasilkan. Pada produksi Opak Singkong, pengusaha Opak tidak menggunakan tenaga kerja dalam keluarga. Pemilik usaha Opak hanya mengawasi kegiatan produksi.

\section{Biaya Produksi Opak Singkong}

Biaya produksi Opak Singkong adalah keseluruhan dari biaya yang dikeluarkan ataupun digunakan oleh responden pengusaha Opak Singkong. Adapun biaya-biaya tersebut dapat digolongkan pada biaya tetap (fixed cost) dan biaya berubah (variable cost).

\section{a. Biaya tetap (fixed cost)}

Biaya tetap (fixed cost) pada produksi Opak Singkong adalah biaya yang tidak mengalami perubahan dalam jangka pendek meskipun produksi Opak Singkong yang 
dihasilkan berubah. Adapun biaya tetap terdiri dari; biaya sewa tanah apabila tempat usaha produksi Opak Singkong responden tidak menggunakan tanah sendiri, biaya penyusutan alat, dan biaya tenaga kerja. Adapun biaya tetap tersebut sebagaimana pada Tabel 1 .

Tabel 1

Rata-rata Biaya tetap (fixed cost) Usaha Opak Singkong

\begin{tabular}{llc}
\hline \hline No & \multicolumn{1}{c}{ Uraian } & Jumlah \\
\hline 1 & Biaya Tenaga kerja & 634666.7 \\
2 & Biaya Penyusutan & 9830.87 \\
\hline \hline & Jumlah & 644497.5 \\
\hline \hline
\end{tabular}

Sumber: Analisis data primer

Tabel 1 menunjukkan bahwa rata-rata biaya tetap (fixed cost) yang digunakan untuk memproduksi Opak Singkong setiap produksi adalah Rp. 644.497,5 Adapun biaya-biaya penyusutan terdiri dari biaya penyusutan mesin diesel, mesin gilingan, mesin press, mesin pencetak, dandang besar untuk merebus Singkong kereta sorong, ayakan, ember, plastik hitam alas untuk menjemur Opak dan sekop.

\section{b. Biaya berubah (variable cost)}

Biaya berubah (variable cost) pada produksi Opak Singkong adalah biaya yang mengalami perubahan dalam jangka pendek apabila jumlah produksi Opak Singkong berubah. Adapun biaya berubah terdiri dari; biaya bahan baku utama berupa Singkong dan bahan baku penolong antara lain bahan bakar, kayu bakar dan karung untuk pengemasan produk jadi Opak Singkong.

Tabel 2

Rata-rata biaya berubah (variable cost) produksi Opak Singkong

\begin{tabular}{llc}
\hline \hline N0. & Uraian & Jumlah (Rp) \\
\hline \hline 1 & Singkong & 3173166.67 \\
2 & Kayu bakar & 117500 \\
3 & Bahan bakar & 45866.67 \\
4 & Karung & 42916.67 \\
\hline \hline & Jumlah & 3379450.01 \\
\hline
\end{tabular}

Sumber: Analisis data primer

Dari tabel 2 dapat diketahui biaya berubah responden pengusaha Opak Singkong pada setiap produksi adalah Rp. 3.379.450.01. Pembelian bahan baku utama berupa Singkong merupakan biaya berubah paling besar dibandingkan dengan biaya lainnya. Besarnya ratarata biaya pembelian Singkong Rp.3.173.166,67 menunjukkan bahwa pengusaha Opak Singkong dalam sekali produksi Opak sudah dalam skala besar. Jumlah Singkong yang di produksi rata-rata adalah 2,4 ton dengan penggunaan tenaga kerja 13 orang.

\section{c. Biaya Explisit dan Biaya Implisit}

Pada produksi Opak Singkong terdapat biaya explisit dan biaya implisit, adapun biaya explisit pada penelitian adalah keseluruhan biaya yang nyata dikeluarkan oleh pengusaha Opak pada setiap produksi. Dengan demikian dalam hal ini biaya tetap (fixed cost) merupakan biaya explisit yaitu sebesar Rp.644.497,5. 
Biaya implisit merupakan biaya yang tidak nyata dikeluarkan oleh pengusaha. Dalam hal ini biaya implisit adalah sewa tempat usaha dan bunga modal sendiri. Pengusaha dalam memproduksi Opak Singkong tidak menggunakan tenaga kerja dalam keluarga. Adapun pemilik usaha atau pengusaha hanya mengontrol berlangsungnya kegiatan produksi.

Tabel 3

Biaya Implisit Produksi Opak Singkong

\begin{tabular}{|c|c|c|}
\hline No & Uraian & Jumlah \\
\hline 1 & Biaya sewa tempat usaha & 12500 \\
\hline \multirow[t]{2}{*}{2} & Bunga modal sendiri & 510.07 \\
\hline & Jumlah & 13010.07 \\
\hline
\end{tabular}

Sumber: Analisis data primer

\section{d.Biaya Total (Total Cost) produksi Opak Singkong}

Biaya Total (Total Cost) dalam produksi Opak Singkong terdiri dari biaya tetap (fixed cost), biaya berubah (variable cost) dan biaya implisit.

Tabel 4

Total biaya produksi Opak Singkong

\begin{tabular}{llc}
\hline \hline No & \multicolumn{1}{c}{ Uraian } & Jumlah \\
1 & Biaya tetap (fixed cost) & 644497.5 \\
2 & Biaya berubah (variabel cost) & 3379450.01 \\
3 & Biaya implisit & 13010.07 \\
\hline \hline Jumlah & & 4036957.58 \\
\hline \hline
\end{tabular}

Sumber: Analisis data primer

\section{Penerimaan dan Keuntungan Usaha Opak Singkong}

Kegiatan produksi Opak Singkong responden yang terdapat di desa Tuntungan II Kabupaten Deli Serdang masih bergantung dengan kondisi lingkungan dan alam. Apabila musim hujan pengusaha akan mengalami kendala pada proses penjemuran. Kondisi cuaca yang mendung dan turun hujan tidak memungkinkan untuk melakukan kegiatan pengolahan. Disamping itu pengusaha Opak Singkong juga bergantung pada ketersediaan bahan baku utama yaitu Singkong segar. Rata-rata jumlah penerimaan responden adalah Rp.5.067.550,00. Adapun rata-rata jumlah Opak Singkong yang dihasilkan sebanyak 785,67 Kg pada setiap satu kali produksi. Keuntungan pengusaha Opak Singkong adalah selisih dari total penerimaan dengan total biaya yaitu sebesar Rp. 1.030.592,42.

\section{Analisis Kelayakan Usaha Opak Singkong}

Menurut Thunk dalam Thoha (2000) bahwa ada enam faktor yang menjelaskan eksistensi industri kecil, yaitu : pertama, dampak transportasi dimana biaya transportasi mempunyai pengaruh yang signifikan terhadap biaya pemasaran untuk jenis barang tertentu atau pada tingkat retail ; kedua adalah pengaruh ukuran; ketiga adalah pengaruh penyesuaian dimana perusahaan kecil lebih mudah melakukan penyesuaian pada output dengan biaya yang lebih rendah dibandingkan dengan perusahaan besar karena mereka lebih padat karya atau menggunakan peralatan yang lebih sederhana; keempat adalah efektifitas, sebagai contoh pakaian yang diproduksi secara massal dengan harga yang lebih murah, nilainya akan lebih rendah bagi sebagian konsumen dibandingkan dengan pakaian yang dijahit secara 
khusus oleh penjahit kecil; kelima adalah pengaruh pengendalian dimana biaya pengendalian untuk industri kecil lebih rendah dibanding industri besar terutama industri yang berhubungan dengan seni atau kerajinan dan membutuhkan perlakuan yang khusus; keenam adalah berkaitan dengan perubahan dalam teknologi dan globalisasi.

Faktor bahan baku Singkong merupakan bahan utama untuk memperoduksi Opak Singkong. Ketersediaan Singkong menjadi hal penting. Tetapi dalam perkembangannya pengusaha Opak menghadapi kendala untuk mendapatakan Singkong. Dan hal tersebut ditunjukkan dengan berkurangnya jumlah pengusaha dalam memproduksi Opak Singkong.

Apabila ditinjau dari aspek kelayakan usaha, hasil analisis menunjukkan bahwa perbandingan penerimaan dan total biaya produksi adalah 1,26. Dengan hasil R/C yang lebih besar dari satu maka dapat dikatakan bahwa usaha Opak Singkong tersebut layak untuk dilanjutkan. Adapun faktor Singkong yang terbatas, disebabkan usaha tani Singkong di desa Tuntungan berkurang. Petani Singkong banyak yang menjual lahannya untuk dijadikan tanah kaplingan. Dan ada juga yang disebabkab pembagian tanah warisan di keluarga. Adapun sebagian pengusaha Singkong memperoleh bahan baku Singkong dari luar desa Tuntungan II.

\section{Pola dan Lembaga Pemasaran Opak Singkong}

Produksi Opak Singkong yang dihasilkan masih dalam bentuk mentah dan tidak memiliki rasa tertentu. Untuk mengkonsumsi Opak tersebut harus diolah lagi seperti digoreng. Dan juga harus menambahkan bumbu-bumbu tertentu sehingga Opak memiliki rasa tertentu. Pemasaran Opak Singkong responden di desa Tuntungan II disamping di pasarkan di kota Medan juga sampai ke Jakarta, Riau, Padang dan Palembang. Adapun pasar yang menampung Opak Singkong adalah pabrik-pabrik makanan yang mengolah kembali Opak Singkong menjadi produk makanan cemilan dengan cita rasa tertentu.

Produk Opak Singkong yang telah jadi tidak dipasarkan melalui agen pengumpul. Adapun pemasarannya adalah pihak pabrik langsung datang ke tempat pengolahan Singkong dengan menggunakan truk. Dengan demikian pengusaha Opak Singkong dalam usahanya sebagai produsen dan penjual. Opak Singkong yang telah dikemas dalam karung-karung langsung di muat dalam truk. Dengan demikian, pengusaha Opak tidak mengeluarkan biaya muat dan biaya transportasi.

Pola pemasaran Opak Singkong tidak menggunakan rantai pemasaran yang panjang. Terdapat pola pemasaran sebagai berikut:

a. Pengusaha Opak sekalian penjual - pabrik makanan cemilan di Jakarta

b. Pengusaha Opak sekalian penjual - pabrik makanan cemilan di Palembang

c. Pengusaha Opak sekalian penjual - pabrik makanan cemilan di Tanjung Morawa (Sumatera Utara)

Pengusaha Opak dalam pemasaran Opak tersebut tidak mengetahui produksi lanjutan dari Opak setelah sampai pada pabrik-pabrik cemilan. Mereka hanya tau bahwa Opak tersebut akan diolah lebih labjut untuk menjadi makanan cemilan dengan berbagai rasa. Bahkan pabrik makanan cemilan di Jakarta juga melakukan expor produk lanjutan Opak ke Malaysia. Demikian pula dalam pengambilan data di lokasi penelitian, supir truk yang membawa Opak ke Jakarta, Palembang dan Tanjung Morawa tidak memberikan informasi terkait dengan produk lanjutan dari Opak sehingga sampai ke konsumen baik nama produk dan harganya. Pengusaha hanya berprinsip yang penting Opak mereka diangkut ke truk dan mereka mendapatkan penerimaan. Pengusaha Opak hanya berinteraksi langung dengan supir truk yang diutus dari pabrik. Setelah Opak-opak dimuat oleh kernek truk, pengusaha mendapat hasil penerimaannya. 


\section{Margin Keuntungan Pemasaran}

Pada penelitian tidak dapat diketahui margin keuntungan pemasaran. Hal tersebut karena pemasaran Opak hanya terdapat satu rantai pemasaran. Dan tidak diperoleh informasi tentang tingkat harga dari produk lanjutan Opak Singkong. Pengusaha tidak ada yang menjual Opak secara eceran. Masing-masing pengusaha sudah memiliki pembeli langganan yaitu pabrik makanan cemilan seperti di Jakarta, Palembang dan Tanjung Morawa.

Dengan demikian hal tersebut menunjukkan bahwa informasi pemasaran dari Opak bersifat asimetris. Dimana pengusaha Opak tidak memperoleh informasi tentang kelanjutan dari produk olahan mereka. Dan dari beberapa responden pengusaha yang memiliki kapasitas produksi menggunakan bahan baku di bawah satu ton, akhirnya keluar dari pasar. Menurut perhitungan mereka bahwa usaha mereka tidak memberikan hasil yang seimbang. Dengan produksi yang terbatas mereka juga akan memperoleh penerimaan terbatas. Sementara mereka juga harus mengeluarkan biaya produksi pengolahan Opak. Hanya pengusaha dengan modal besar yang mampu untuk bertahan.

\section{E. KESIMPULAN DAN SARAN Kesimpulan}

1. Untuk memproduksi Opak Singkong, pengusaha menggunakan biaya tetap (fixed cost) Rp.644.497,5 dan biaya berubah (variable cost) Rp.3.379.450,01. Adapun biaya implisit sebesar Rp.13.010,07. Sehingga rata-rata biaya total (total cost) untuk setiap produksi Opak Singkong adalah Rp. 4.036.957,58. Penggunaan biaya yang besar terdapat pada pembelian bahan baku utama yaitu Singkong dengan penggunaan biaya sebesar Rp.3.173.166,67. Untuk setiap produksi Singkong yang digunakan rata-rata 2,4 ton.

2. Penerimaan pengusaha dari setiap produksi Opak adalah Rp.5.067.550,00 dengan jumlah produksi rata-rata 785,67 $\mathrm{Kg}$ dengan harga $\mathrm{Rp} .6 .450,00 / \mathrm{Kg}$. Dengan demikian rata-rata keuntungan yang diperoleh pengusaha pada setiap produksi Opak adalah Rp.1.030.592,42.

3. Hasil analisis kelayakan menunjukkan bahwa R/C sebesar 1,26. Dengan demikian kegiatan Usaha Kecil dan Menengah (UKM) Opak Singkong layak untuk dilanjutkan.

4. Produk Opak yang akan dipasarkan adalah dalam bentuk mentah dan alami tanpa rasa tertentu. Untuk mengkonsumsinya harus diolah kembali sehingga menghasilkan makanan yang bercita rasa. Pola pemasaran Opak Singkong adalah pengusaha Opak selain sebagai produsen juga sebagai penjual kepada pabrik cemilan di Jakarta, Palembang dan Tanjung Morawa.

5. Pengusaha dalam memasarkan Opak Singkong yang dihasilkan tidak mengeluarkan biaya transportasi. Opak yang sudah dikemas akan diangkut oleh truk yang diutus oleh pabrik cemilan dari Jakarta, Palembang dan Tanjung Morawa. Supir truk tidak mengetahui produk lanjutan dari Opak Singkong dan pemasaran Opak tersebut. Informasi pemasaran Opak tidak jelas diketahui sehingga margin keuntungan pemasaran Opak Singkong di desa Tuntungan II Kabupaten Deli Serdang tidak diketahui.

\section{Saran}

1. Pihak pabrik yang menjadi konsumen pengusaha Opak seharusnya membangun hubungan kerjasama yang lebih baik dengan saling memberikan informasi pasar yang saling menguntungkan.

2. Dibutuhkan adanya sebuah wadah perkumpulan pengusaha Opak Singkong desa Tuntungan II untuk meningkatkan kemampuan mereka dalam mengelola usaha baik dari aspek finansial dan operasional usaha. Disamping itu untuk mengatasi berbagai kendala dan masalah sehingga dapat diselesaikan bersama.

3. Diperlukan adanya kerjasama yang kuat antara pengusaha Opak dengan petani Singkong. 


\section{DAFTAR PUSTAKA}

Hanif dan Dyah. 2012. Keragaan Agroindustri Opak Singkong di Desa Jolontoro Kecamatan Sapuran Kabupaten Wonosobo. Jurnal Surya Agritama Vol. 1 No. 1 Maret 2012.

Harahap, Mailina. 2013. Analisis Pengembangan Usaha Kecil Menengah (UKM) Kerupuk Tempe di Kabupaten Langkat Provinsi Sumatera Utara. Jurnal Manajemen dan Bisnis. Vol. 13 No. 01 Oktober 2013.

Nazir, Moh. 1999. Metode Penelitian. Ghalia. Jakarta.

Putong, Iskandar. 2005. Teori Ekonomi Mikro. Mitra Wacana Mulia. Jakarta.

Simatupang, P. 1994. Prosiding Seminar Sehari Peranan Strategis Industri Kecil dalam PJPT II Jakarta, 22 Juli 1993. LP UKI Press Jakarta.

Sudiyono .2002. Pemasaran Pertanian. UMM Press. Malang.

Tambunan, 2000. Perekonomian Indonesia Beberapa Isu Penting. Ghalia Indonesia, Jakarta.

Thoha, M. 1997. Kondisi, Kendala dan Prospek Industri Kecil dalam Menghadapi Era Globalisasi. Makalah disampaikan pada Acara Seminar Sehari di PDII - LIPI.

Widiastuti dan Harisudin. 2013. Saluran dan Marjin Pemasaran Jagung di Kabupaten Grobogan. Jurnal SEPA Vol.9 No.2. Februari 2013.

(http://www.dprin.go.id/idkm). 